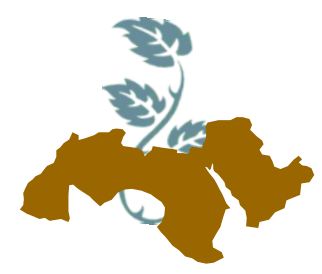

Arab Univ.

J. Agric. Sci., Ain Shams Univ., Cairo Special Issue, 26(2B), 1439-1448, 2018

\title{
EFFECTS OF NANO CARBON AND NITROGEN FERTILIZATION ON GROWTH, LEAF MINERAL CONTENT, YIELD AND FRUIT QUALITY OF FLAME SEEDLESS GRAPE
}

\author{
Rasha, S. Abdel-Hak'; El-Shazly ${ }^{2}$ S.A.; El-Gazzar² A.A. and Shaaban ${ }^{1}$ E.A.
}

1- Pomology Dept., National Research Centre, Dokki, Giza, Egypt

2- Horticulture Dept., Fac. of Agric., Ain Shams Univ., P.O. Box 68, Hadayek Shobra 11241, Cairo, Egypt

Keywords: Nano technology, Carbon nano tubesFlame seedless grape-Leaf mineral content- YieldFruit quality.

\section{ABSTRACT}

This investigation was carried out through two successive seasons (2014 and 2015) to investigate the effects of nano-carbon and nitrogen fertilization levels on growth, leaf mineral content, yield and fruit quality of 3 years old flame seedless grapevines, cultivated in a private orchard with loamy soil texture, at Gharbiya Governorate. Ten treatments were applied as a randomized complete block design with three replications. The result indicated that $80 \% \mathrm{~N}$ from recommended requirment+ $0.6 \%$ carbon nano tubes (CNTs) increased significantly leaf area, fresh and dry weight, total carbohydrate $\%$ and concentration of $\mathrm{N}, \mathrm{P}, \mathrm{K}, \mathrm{Mg}$, and $\mathrm{Fe}$ in leaves, weight of 100 berries, and juice weight of 100 berries compared with control. Also results showed that yield of combined application of $80 \%$ conventional fertilizer of nitrogen and nano-carbon at $0.6 \%$ was equal to that with supplied $100 \%$ conventional fertilizer (control). This indicated that the utilization rate of nitrogen fertilizer was increased after combined application of nano-carbon, which can save the $\mathrm{N}$ fertilizer amounts in production practice.

\section{INTRODUCTION}

Grape is considered as one of the most popular and favorite fruit crops in the world, for being of an excellent flavor, nice taste and high nutritional value. In Egypt, it ranks the second fruit crops and is consumed mainly as fresh fruits. The cultivated area has grown rapidly in the last two decades and reached 196900 feddans (M.A.L.R., 2015).

Fertilizers have an axial role in enhancing the food production in developing countries especially after the introducing of high yielding and fertilizer responsive crop varieties. Moreover, excessive amounts of nitrogen fertilizers affect the groundwater and lead to eutrophication in aquatic ecosystems. Such cases along with the fact that the fertilizer use efficiency is about 20-50 percent for nitrogen fertilizers implies that food production will have to be much more efficient than ever before (Shaviv, 2000; Chinnamuthu and Boopathi, 2009).

Nitrogen has a pronounced role in improving production and quality of fruits. Nitrogen plays a key role in the nutrition of plants. As a matter of fact, plant life would not be possible without this element. Nitrogen has many functions in the synthesis of proteins, protoplasm, enzymes, and organic compounds such as nucleic proteins, amino acids, polypeptides and chlorophylls. (Tisdale et al 1985)

The effect of nanoparticles in plants varies according to their composition, size, physical and chemical properties, as well as the plant species since the nanoparticles interact through enhancing production or inhibitory effects on plant growth in the different developmental stages (Ma et al 2010).

These physical and chemical features of carbon nanomaterials have been used in agriculture to increase the crop yield, mainly in the germination process, root growth, and photosynthesis. However, many other plant interaction mechanisms exist, including absorption, accumulation, 
transportation, or rejection of the nanoparticles; which have not been fully studied despite of the rapid progress in the development of this technology (Liu et al 2009).

Carbon nanotubes can stimulate growth, gene and protein expression of aquaporin in tobacco cells (Khodakovskaya et al 2012) it may also trigger the reproductive genes in similar other plants. The penetration of CNTs into the plant system is inversely proportional to its size and it is the key factor to increase the plant growth and productivity. This investigation was carried out to study the effect of different concentrations of carbon nano tubes and nitrogen fertilization on growth, leaf min- eral content, yield and fruit quality of Flame seedless grapevine.

\section{MATERIALS AND METHODS}

The present study was carried out during two successive seasons 2014 and 2015 on Flame seedless grapes (Vitis vinifera L.). Grapevines were about 3 years old and trained on cordon system with double cordon, spur pruning (each with 23 eyes) and planted at $1.5 \times 3.5$ meter apart under flood irrigation system on loamy soil in a private orchard, at Gharbiya Governorate, Egypt. Full description of the tested soil is given in Table (1).

Table1. Physical and chemical properties of the experimental soil.

\begin{tabular}{|l|c|c|c|c|c|c|c|c|}
\hline \multicolumn{10}{|c|}{ Physical analysis } \\
\hline Soil depth & Sand \% & Silt \% & Clay\% & Texture & $\mathbf{p H}$ & $\mathbf{E C ~ ( d s / m )}$ & CaCO $_{3} \%$ & $\begin{array}{c}\text { Organic } \\
\text { matter\% }\end{array}$ \\
\hline $\mathbf{0 - 3 0 ~ c m ~}$ & 10.8 & 44 & 45.2 & loamy & 8.4 & 0.5 & 1.2 & 1.6 \\
$\mathbf{3 0 - 6 0} \mathbf{~ c m}$ & 12.8 & 44 & 43.2 & loamy & 8.4 & 0.4 & 2 & 1.1 \\
\hline \multicolumn{8}{|c|}{ Chemical analysis } \\
\hline Soil depth & N \% & P \% & K \% & Ca\% & Mg\% & Fe (ppm) & Zn(ppm) & Mn (ppm) \\
$\mathbf{0 - 3 0 ~ c m ~}$ & 0.13 & 0.6 & 0.9 & 4.2 & 1.1 & 7.8 & 3.4 & 3.2 \\
$\mathbf{3 0 - 6 0 ~ c m ~}$ & 0.10 & 0.6 & 0.6 & 3.4 & 0.9 & 5.5 & 2.4 & 1.8 \\
\hline
\end{tabular}

Grapevines received normal cultural practices as well as soil fertilized with the recommended $\mathrm{N}$ fertilization level $(50 \mathrm{gN} /$ vine / year) in both organic and mineral forms (control). The nitrogen used was ammonium sulphate.
In this study three rates of nitrogen fertilization ( $80 \%, 60 \%$ and $40 \%$ ) from the recommended level + three rates of multi walled carbon nano tubes(MCNTs) $(0.2 \%, 0.4 \%$ and $0.6 \%)$ from the nitrogen amount in each rate were applied to the vines. MCNTs were purchased from Sigma Aldrich; its diameter is $110-170 \mathrm{~nm}$, length: $5-9$ micron.

Treatments:

\begin{tabular}{|l|l|}
\hline $100 \% \mathrm{MN} 50 \mathrm{gN} /$ Vine/year & (control) \\
\hline $80 \% \mathrm{MN}(40 \mathrm{gN} /$ vine/year) & $0.2 \%$ CNTs from total nitrogen \\
& $0.4 \%$ CNTs from total nitrogen \\
& $0.6 \%$ CNTs from total nitrogen \\
\hline $60 \% \mathrm{MN}(30 \mathrm{gN} /$ vine/year) & $0.2 \%$ CNTs from total nitrogen \\
& $0.4 \%$ CNTs from total nitrogen \\
& $0.6 \%$ CNTs from total nitrogen \\
\hline $40 \% \mathrm{MN}(20 \mathrm{gN} /$ vine/year) & $0.2 \%$ CNTs from total nitrogen \\
& $0.4 \%$ CNTs from total nitrogen \\
& $0.6 \%$ CNTs from total nitrogen \\
\hline
\end{tabular}

$\mathrm{MN}$ : Mineral nitrogen

CNTs: Carbon nano tubes

Arab Univ. J. Agric. Sci., Special Issue, 26(2B), 2018 


\section{Statistical analysis}

The experiment was set up in a randomized complete block design with three replicates and each replicate was one vine. All data obtained during this study were statistically analyzed and the differences between means at probability of $5 \%$ were differentiated using Duncan's multiple rang test (Duncan, 1955).

\section{Measurements}

\section{1-Vegetative measurements}

Average leaf area $\left(\mathrm{cm}^{2}\right)$ was measured using the fifth full expanded mature leaf from the shoot tip of each vine in mid-july by planimeter. Average leaf fresh and dry weight was determined as gram, average branch length and diameter were determined as $\mathrm{cm}$ and number of leaves/branch was counted.

\section{2- Chemical measurements}

2.1. Leaf total chlorophyll was colorimetrically determined in fresh leaf samples according to Wood et al (1992) by using Minolta chlorophyll meter SPAD 502.

2.2. Total carbohydrates $\%$ during the dormancy period (the last week of January), samples were taken from the basal part of shoots and were determined according to Smith et al (1956).

2.3. Leaf mineral content: Further in mid-July, 20 leaves sample include blade and petiole $\left(6^{\text {th }}\right.$ leaf from the shoot tip) of each vine were collected to determine leaf mineral contents. Leaves were washed with distilled water then oven dried at 60 $70^{\circ}$ c until a constant weight. The dried samples were ground in a stainless steel knife mill and 0.2 gram of the ground material of each sample was digested using a mixture of perchloric: sulphoric acid1:10(v/v)according to (Jackson, 1967). Nitrogen was determined as the method described by Pregl (1945), while phosphorus was colorimetrically determined as the method of Truog and Meyer (1929), potassium was determined using flame photometer according to the method of Brown and Lilleland (1946) and iron, zinc and manganese were measured using the atomic absorption apparatus according to the method of Cotteine et al (1982).

\section{3-Yield and fruit quality}

3.1. Yield/vine $(\mathbf{k g})$ : harvested at the ripening stage when TSS\% reached $16 \%$ and color covered all bunch berries, clusters number per vine were counted and weighted to estimate total yield per vine $\mathrm{kg}$.

\subsection{Fruit quality \\ a- Physical properties}

Average cluster dimension (length and width as $\mathrm{cm})$, average cluster weight $(\mathrm{g})$, the weight of 100 berries ( $\mathrm{g}$ ) and juice weight/ 100 berries $(\mathrm{g})$ were determined.

\section{b- Chemical properties:}

Total soluble solids percentage in berry juice (TSS \%) were determined using hand refractometer and total titratable acidity\% was expressed as tartaric acid/100ml juice (A.O.A.C, 1985). Total anthocyanins of the berry skin $(\mathrm{mg} / 100 \mathrm{~g}$ fresh weight) were determined according to Husia et al (1965).

\section{RESULTS AND DISCUSSION}

\section{Effect on vegetative growth}

Results presented in Table (2) indicated that T4 was significantly affected leaf area, leaf fresh weight and leaf dry weight, comparing with all other treatments. On the other hand, the reverse was true with the vines which fertilized with T8 $(40 \% \mathrm{~N}+0.2 \% \mathrm{CNT})$, since they reflected the least values of leaf area, leaf fresh weight and leaf dry weight in the two seasons of the study.

These results are matched with those of Haghighi and Teixeira da Silva (2014) who found that fresh weight of radish seedlings was decreased as the CNTs concentration increased.

With regard to the response of Flame seedless grapes to nitrogen fertilization and CNTs rates. Results tabulated in Table (3) reveal obviously that the highest significant values of branch length and No. of leaves /branch were achieved when the vines were fertilized with T4 $(80 \% \mathrm{~N}+0.6 \% \mathrm{CNT})$ with no significant difference than the control treatment (T1). Also it was found no significant difference among treatments in branch diameter compared to control. T4 affected significantly total 
Table 2. Effect of nano carbon and nitrogen fertilization rates on leaf area, leaf fresh and dry weight of Flame seedless grapes in 2014 and 2015 seasons

\begin{tabular}{|c|c|c|c|c|c|c|}
\hline \multirow{2}{*}{ Treatment } & \multicolumn{2}{|c|}{ Leaf area(cm2) } & \multicolumn{2}{c|}{ Leaf fresh weight(g) } & \multicolumn{2}{c|}{ Leaf dry weight(g) } \\
\cline { 2 - 7 } & $\mathbf{2 0 1 4}$ & $\mathbf{2 0 1 5}$ & $\mathbf{2 0 1 4}$ & $\mathbf{2 0 1 5}$ & $\mathbf{2 0 1 4}$ & $\mathbf{2 0 1 5}$ \\
\hline $100 \% \mathrm{~N}$ (Cont.) & $197.02 \mathrm{c}$ & $201.04 \mathrm{c}$ & $4.70 \mathrm{~b}$ & $4.6 \mathrm{~b}$ & $1.39 \mathrm{bc}$ & $1.12 \mathrm{~d}$ \\
$80 \% \mathrm{~N}+0.2 \mathrm{CNTS}$ & $180.71 \mathrm{~d}$ & $191.38 \mathrm{~d}$ & $3.80 \mathrm{~d}$ & $3.7 \mathrm{c}$ & $1.30 \mathrm{~cd}$ & $1.14 \mathrm{~cd}$ \\
$80 \% \mathrm{~N}+0.4 \mathrm{CNTS}$ & $206.51 \mathrm{~b}$ & $208.51 \mathrm{~b}$ & $4.13 \mathrm{c}$ & $4.3 \mathrm{~b}$ & $1.52 \mathrm{~b}$ & $1.4 \mathrm{~b}$ \\
$80 \% \mathrm{~N}+0.6 \mathrm{CNTS}$ & $218.71 \mathrm{a}$ & $221.71 \mathrm{a}$ & $5.50 \mathrm{a}$ & $5.4 \mathrm{a}$ & $1.72 \mathrm{a}$ & $1.58 \mathrm{a}$ \\
$60 \% \mathrm{~N}+0.2 \mathrm{CNTS}$ & $144.03 \mathrm{j}$ & $171.43 \mathrm{e}$ & $3.13 \mathrm{ef}$ & $3.4 \mathrm{c}$ & $1.23 \mathrm{de}$ & $0.99 \mathrm{de}$ \\
$60 \% \mathrm{~N}+0.4 \mathrm{CNTS}$ & $176.62 \mathrm{e}$ & $188.96 \mathrm{~d}$ & $3.40 \mathrm{e}$ & $3.4 \mathrm{c}$ & $1.33 \mathrm{~cd}$ & $0.99 \mathrm{de}$ \\
$60 \% \mathrm{~N}+0.6 \mathrm{CNTS}$ & $176.61 \mathrm{f}$ & $190.60 \mathrm{~d}$ & $3.40 \mathrm{e}$ & $3.7 \mathrm{c}$ & $1.40 \mathrm{bc}$ & $1.3 \mathrm{bc}$ \\
$40 \% \mathrm{~N}+0.2 \mathrm{CNTS}$ & $157.61 \mathrm{i}$ & $161.27 \mathrm{f}$ & $2.87 \mathrm{f}$ & $2.8 \mathrm{~d}$ & $1.11 \mathrm{e}$ & $0.94 \mathrm{e}$ \\
$40 \% \mathrm{~N}+0.4 \mathrm{CNTS}$ & $163.11 \mathrm{~h}$ & $166.11 \mathrm{ef}$ & $3.20 \mathrm{ef}$ & $3.3 \mathrm{c}$ & $1.12 \mathrm{e}$ & $0.89 \mathrm{e}$ \\
$40 \% \mathrm{~N}+0.6 \mathrm{CNTS}$ & $165.71 \mathrm{~g}$ & $170.37 \mathrm{e}$ & $3.30 \mathrm{e}$ & $3.3 \mathrm{c}$ & $1.23 \mathrm{de}$ & $0.91 \mathrm{e}$ \\
\hline
\end{tabular}

Means having the same letter(s) within a column are insignificantly different at $5 \%$ level

Table 3. Effect of nano carbon and nitrogen fertilization rates on branch length, branch diameter, no. of leaves /branch, total chlorophyll and total carbohydrate of Flame seedless grapes in 2014 and 2015 seasons

\begin{tabular}{|c|c|c|c|c|c|c|c|c|c|c|}
\hline \multirow[t]{2}{*}{ Treatment } & \multicolumn{2}{|c|}{$\begin{array}{l}\text { Branch length } \\
\text { (cm) }\end{array}$} & \multicolumn{2}{|c|}{$\begin{array}{c}\text { Branch } \\
\text { diameter } \\
(\mathrm{mm})\end{array}$} & \multicolumn{2}{|c|}{$\begin{array}{l}\text { No. leaves } \\
\text { /branch }\end{array}$} & \multicolumn{2}{|c|}{$\begin{array}{l}\text { Total Chlorophyll } \\
\text { (SPAD) value }\end{array}$} & \multicolumn{2}{|c|}{$\begin{array}{c}\text { Total } \\
\text { Carbohydrate } \\
\%\end{array}$} \\
\hline & 2014 & 2015 & 2014 & 2015 & 2014 & 2015 & 2014 & 2015 & 2014 & 2015 \\
\hline $100 \% \mathrm{~N}$ (Cont.) & $56.34 \mathrm{a}$ & $55.01 \mathrm{ab}$ & $0.88 \mathrm{a}$ & $0.83 a$ & $26.98 \mathrm{a}$ & $26.60 \mathrm{ab}$ & $34.03 a b$ & $34.36 \mathrm{abc}$ & $5.80 \mathrm{~b}$ & $6.13 a$ \\
\hline $80 \% \mathrm{~N}+0.2 \mathrm{CNTS}$ & $50.63 a b$ & $50.63 \mathrm{bc}$ & $0.83 a$ & $0.86 a$ & $22.66 \mathrm{bc}$ & $24.65 b$ & 30.00 bcde & 31.33abcde & $4.05 \mathrm{fg}$ & $5.11 \mathrm{~b}$ \\
\hline $80 \% \mathrm{~N}+0.4 \mathrm{CNTS}$ & $54.33 \mathrm{ab}$ & $55.32 a b$ & $0.80 a$ & $0.80 a$ & $23.28 \mathrm{bc}$ & 25.94 & $32.50 \mathrm{abcd}$ & $33.23 \mathrm{abcd}$ & $4.84 \mathrm{~d}$ & $5.18 b$ \\
\hline $80 \% \mathrm{~N}+0.6 \mathrm{CNTS}$ & $56.67 \mathrm{a}$ & $58.66 a$ & $0.80 a$ & $0.90 \mathrm{a}$ & $27.45 \mathrm{a}$ & $29.11 a$ & $34.80 \mathrm{a}$ & $36.26 a$ & $6.08 \mathrm{a}$ & $6.61 a$ \\
\hline $60 \% \mathrm{~N}+0.2 \mathrm{CNTS}$ & $49.50 \mathrm{ab}$ & 50.86 bc & $0.80 a$ & $0.76 a$ & 20.66 cde & $21.32 \mathrm{c}$ & 29.30 cde & 29.2 cde & $4.48 \mathrm{e}$ & $4.00 \mathrm{~cd}$ \\
\hline $60 \% \mathrm{~N}+0.4 \mathrm{CNTS}$ & $47.3 \mathrm{c}$ & $50.96 \mathrm{bc}$ & $0.73 a$ & $0.73 a$ & $21.23 \mathrm{bcd}$ & $21.56 \mathrm{c}$ & $30.20 \mathrm{bcde}$ & $30.93 \mathrm{bcde}$ & $3.91 \mathrm{~g}$ & $3.91 \mathrm{~cd}$ \\
\hline $60 \% \mathrm{~N}+0.6 \mathrm{CNTS}$ & $49.37 b c$ & $51.37 \mathrm{bc}$ & $0.80 a$ & $0.80 a$ & $23.67 \mathrm{~b}$ & $25.33 b$ & $33.20 \mathrm{abc}$ & $34.63 \mathrm{ab}$ & $5.14 \mathrm{c}$ & $4.8 \mathrm{~b}$ \\
\hline $40 \% \mathrm{~N}+0.2 \mathrm{CNTS}$ & $33.25 d$ & $44.25 \mathrm{c}$ & $0.80 a$ & $0.76 \mathrm{a}$ & $17.89 \mathrm{e}$ & $16.89 d$ & $27.40 \mathrm{e}$ & $27.76 \mathrm{e}$ & $3.29 \mathrm{~h}$ & $3.42 \mathrm{~d}$ \\
\hline $40 \% \mathrm{~N}+0.4 \mathrm{CNTS}$ & $35.27 d$ & $45.94 c$ & $0.80 a$ & $0.76 \mathrm{a}$ & $19.00 \mathrm{de}$ & $19.10 \mathrm{~cd}$ & $28.10 \mathrm{de}$ & $26.98 \mathrm{e}$ & $4.22 \mathrm{f}$ & $3.93 \mathrm{~cd}$ \\
\hline $40 \% \mathrm{~N}+0.6 \mathrm{CNTS}$ & $37.22 d$ & $45.22 \mathrm{c}$ & $0.83 \mathrm{a}$ & $0.83 a$ & 20.44 cde & $20.50 \mathrm{c}$ & 29.10 cde & 28.63de & $4.17 \mathrm{f}$ & $4.14 \mathrm{c}$ \\
\hline
\end{tabular}

Means having the same letter(s) within a column are insignificantly different at $5 \%$ level. 
chlorophyll and total carbohydrate comparing with all other treatments. T3 $(80 \% \mathrm{~N}+4 \% \mathrm{CNT})$ increased significantly total chlorophyll in the both seasons comparing with all other treatments. On the other hand, the least values of branch length and No. of leaves /branch were detected with the vines which received $\mathrm{T} 8(40 \% \mathrm{~N}+0.2 \% \mathrm{CNT})$ in the two seasons of the study.

These results go in line with those reported by Srivastava and Rao (2014) who worked on wheat, maize, peanut and garlic indicated that multi walled carbon nano tubes (CNTs) significantly enhanced plant growth, number and size of leaves and biomass compared to the control. Lahiani et al (2016) proved that carbon- nanomaterials can activate Tobacco growth which was increased by $22 \%$ $46 \%$ when exposed to CNTs. Also, the growth of exposed tomato seedlings was significantly enhanced by the addition of all tested CNTs. On the contrary, the root and shoot lengths of red spinach, lettuce, and cucumber were significantly reduced following exposure to MCNTs compared to control (Begum et al 2014).

\section{Effect on leaf mineral content}

\section{2.a. Macro elements}

In Table (4), it could be observed that T4 had a significant increase in leaves content of $\mathrm{N}, \mathrm{P}, \mathrm{K}$, and $\mathrm{Mg}$ compared with the control. Inconstant trend could be noticed on leaf calcium content between the two studied seasons.

These results are in harmony with those found by Liu and Liao (2008) who reported that the activity of water after addition of nano materials was increased and $\mathrm{N}, \mathrm{P}, \mathrm{K}$ were absorbed into plants during water absorption. Taha et al (2016) found that addition of CNTs to the growing medium of date palm increased the percentages of elements content in the leaves $(\mathrm{N}, \mathrm{P}, \mathrm{K}, \mathrm{Ca}$ ) except $\mathrm{Na}$.

\section{2.b. Micro elements}

It observed from Table (5) that T4 increased significantly $\mathrm{Fe}$ concentration in the leaves in the second season only and insignificantly $\mathrm{Mn}$ and $\mathrm{Zn}$ concentration in the leaves compared with the control.

\section{Effect on yield}

Concerning yield of Flame seedless grapes results presented in Table (6) revealed that, the vines which fertilized with T4 have the highest values of No. Clusters /vine, cluster weight and yield inthe two seasons of the study without significant difference between T4 and the control treatment (T1). There was no significant difference among treatments for cluster weight. Treatments of T3, T4 increased insignificantly No. clusters/vine, cluster weight and yield ( $\mathrm{kg} / \mathrm{vine})$.

On the other hand, the reverse was true when the vines received $\mathrm{T} 8(40 \% \mathrm{~N}+0.2 \% \mathrm{CNTs})$ such treatment gave the least No. clusters/vine, cluster weight and yield in the two seasons.

These results are matched those of Fan et al (2012) who worked on rice and reported that combined application of nitrogen fertilization and nanocarbon increased significantly yield. We found that the yield of combined application of $70 \%$ conventional fertilized and nano-carbon was equal to $100 \%$ conventional fertilizer. Husen and Siddiqi (2014) discovered that carbon nano materials in edible plants and vegetables increased fruit yield up to $118 \%$.

\section{Effect on physical properties}

Regarding the effect of combined nitrogen and CNTs on Flame seedless grapes, results tabulated in Table (7) clearly indicate thatT4 scored the best effect among all treatments. T4 increased significantly weight of 100 berries and juice weight/100 berries compared with all other treatments.

On the other hand, the least value of cluster length and width, weight of 100 berries and juice weight $/ 100$ berries was detected with vines fertilized with T8. Such trend was true in the two seasons.

\section{Effect on chemical properties}

As shown in Table (8) results showed that, T4 increased insignificantly TSS and significantly anthocyanin compared with the control.T7 and T9 recorded lower significant acidity than control treatment. T3 gave similar result as the control treatment in TSS, acidity and anthocyanin as differences were insignificant. T7 had no effects in fruit content of anthocyanin. 
Table 4. Effect of nano carbon and nitrogen fertilization rates on macro nutrients in leaves of Flame seedless grapes in 2014 and 2015 seasons

\begin{tabular}{|c|c|c|c|c|c|c|c|c|c|c|}
\hline \multirow{2}{*}{ Treatment } & \multicolumn{2}{|c|}{ N\% } & \multicolumn{2}{c|}{$\mathbf{P} \%$} & \multicolumn{2}{c|}{ K\% } & \multicolumn{2}{c|}{ Ca\% } & \multicolumn{2}{c|}{ Mg\% } \\
\cline { 2 - 10 } & $\mathbf{2 0 1 4}$ & $\mathbf{2 0 1 5}$ & $\mathbf{2 0 1 4}$ & $\mathbf{2 0 1 5}$ & $\mathbf{2 0 1 4}$ & $\mathbf{2 0 1 5}$ & $\mathbf{2 0 1 4}$ & $\mathbf{2 0 1 5}$ & $\mathbf{2 0 1 4}$ & $\mathbf{2 0 1 5}$ \\
\hline $100 \% \mathrm{~N}$ (Cont.) & $1.24 \mathrm{bc}$ & $1.28 \mathrm{bc}$ & $0.21 \mathrm{a}$ & $0.23 \mathrm{a}$ & $1.62 \mathrm{~cd}$ & $1.82 \mathrm{ab}$ & $1.43 \mathrm{ab}$ & $1.49 \mathrm{a}$ & $0.43 \mathrm{~d}$ & $0.42 \mathrm{ab}$ \\
$80 \% \mathrm{~N}+0.2 \mathrm{CNTS}$ & $1.11 \mathrm{bcd}$ & $1.03 \mathrm{de}$ & $0.18 \mathrm{bc}$ & $0.18 \mathrm{~b}$ & $1.03 \mathrm{e}$ & $1.41 \mathrm{~cd}$ & $1.57 \mathrm{a}$ & $1.47 \mathrm{a}$ & $0.33 \mathrm{fg}$ & $0.35 \mathrm{cde}$ \\
$80 \% \mathrm{~N}+0.4 \mathrm{CNTS}$ & $1.29 \mathrm{~b}$ & $1.36 \mathrm{ab}$ & $0.19 \mathrm{~b}$ & $0.19 \mathrm{~b}$ & $1.74 \mathrm{bc}$ & $1.73 \mathrm{~b}$ & $1.34 \mathrm{ab}$ & $1.43 \mathrm{ab}$ & $0.53 \mathrm{~b}$ & $0.38 \mathrm{bc}$ \\
$80 \% \mathrm{~N}+0.6 \mathrm{CNTS}$ & $1.56 \mathrm{a}$ & $1.43 \mathrm{a}$ & $0.21 \mathrm{a}$ & $0.25 \mathrm{a}$ & $2.16 \mathrm{a}$ & $1.93 \mathrm{a}$ & $1.19 \mathrm{~b}$ & $1.38 \mathrm{bcd}$ & $0.59 \mathrm{a}$ & $0.45 \mathrm{a}$ \\
$60 \% \mathrm{~N}+0.2 \mathrm{CNTS}$ & $1.05 \mathrm{~cd}$ & $1.04 \mathrm{de}$ & $0.17 \mathrm{c}$ & $0.17 \mathrm{bc}$ & $1.38 \mathrm{~d}$ & $1.48 \mathrm{c}$ & $1.47 \mathrm{ab}$ & $1.40 \mathrm{abc}$ & $0.43 \mathrm{~d}$ & $0.39 \mathrm{bc}$ \\
$60 \% \mathrm{~N}+0.4 \mathrm{CNTS}$ & $1.12 \mathrm{bcd}$ & $1.16 \mathrm{~cd}$ & $0.14 \mathrm{~d}$ & $0.15 \mathrm{c}$ & $1.91 \mathrm{ab}$ & $1.53 \mathrm{c}$ & $1.55 \mathrm{a}$ & $1.38 \mathrm{bcd}$ & $0.45 \mathrm{c}$ & $0.36 \mathrm{cde}$ \\
$60 \% \mathrm{~N}+0.6 \mathrm{CNTS}$ & $1.28 \mathrm{~b}$ & $1.31 \mathrm{ab}$ & $0.17 \mathrm{c}$ & $0.17 \mathrm{bc}$ & $1.86 \mathrm{bc}$ & $1.76 \mathrm{ab}$ & $1.57 \mathrm{a}$ & $1.46 \mathrm{ab}$ & $0.36 \mathrm{e}$ & $0.38 \mathrm{bcd}$ \\
$40 \% \mathrm{~N}+0.2 \mathrm{CNTS}$ & $0.92 \mathrm{~d}$ & $0.98 \mathrm{e}$ & $0.17 \mathrm{c}$ & $0.17 \mathrm{bc}$ & $0.98 \mathrm{e}$ & $1.16 \mathrm{e}$ & $1.56 \mathrm{a}$ & $1.37 \mathrm{bcd}$ & $0.34 \mathrm{f}$ & $0.34 \mathrm{de}$ \\
$40 \% \mathrm{~N}+0.4 \mathrm{CNTS}$ & $0.92 \mathrm{~d}$ & $0.93 \mathrm{e}$ & $0.17 \mathrm{c}$ & $0.17 \mathrm{bc}$ & $1.79 \mathrm{bc}$ & $1.30 \mathrm{de}$ & $1.42 \mathrm{ab}$ & $1.33 \mathrm{~cd}$ & $0.41 \mathrm{~d}$ & $0.36 \mathrm{~cd}$ \\
$40 \% \mathrm{~N}+0.6 \mathrm{CNTS}$ & $0.98 \mathrm{~d}$ & $0.98 \mathrm{e}$ & $0.17 \mathrm{c}$ & $0.16 \mathrm{bc}$ & $1.91 \mathrm{ab}$ & $1.27 \mathrm{de}$ & $1.46 \mathrm{ab}$ & $1.29 \mathrm{~d}$ & $0.31 \mathrm{~g}$ & $0.32 \mathrm{e}$ \\
\hline
\end{tabular}

Means having the same letter(s) within a column are insignificantly different at $5 \%$ level.

Table 5. Effect of nano carbon and nitrogen fertilization rates on micro nutrients in leaves of Flame seedless grapes in 2014 and 2015 seasons

\begin{tabular}{|l|l|l|l|l|l|l|}
\hline \multirow{2}{*}{ Treatment } & \multicolumn{2}{|c|}{ Fe (ppm) } & \multicolumn{2}{c|}{ Zn (ppm) } & \multicolumn{1}{c|}{ Mn(ppm) } \\
\cline { 2 - 7 } & \multicolumn{2}{|c|}{$\mathbf{2 0 1 4}$} & \multicolumn{1}{c|}{$\mathbf{2 0 1 5}$} & \multicolumn{1}{c|}{$\mathbf{2 0 1 4}$} & \multicolumn{1}{c|}{$\mathbf{2 0 1 4}$} & \multicolumn{1}{c|}{$\mathbf{2 0 1 5}$} \\
\hline $100 \% \mathrm{~N}($ Cont.) & $135.50 \mathrm{a}$ & $133.70 \mathrm{~b}$ & $50.07 \mathrm{a}$ & $49.09 \mathrm{ab}$ & $114.50 \mathrm{ab}$ & $116.83 \mathrm{ab}$ \\
$80 \% \mathrm{~N}+0.2 \mathrm{CNTS}$ & $134.83 \mathrm{a}$ & $132.76 \mathrm{~b}$ & $47.08 \mathrm{abc}$ & $46.74 \mathrm{abc}$ & $112.97 \mathrm{ab}$ & $113.6 \mathrm{bcd}$ \\
$80 \% \mathrm{~N}+0.4 \mathrm{CNTS}$ & $135.43 \mathrm{a}$ & $133.43 \mathrm{~b}$ & $40.50 \mathrm{de}$ & $40.5 \mathrm{e}$ & $107.43 \mathrm{~b}$ & $113.2 \mathrm{~cd}$ \\
$80 \% \mathrm{~N}+0.6 \mathrm{CNTS}$ & $136.40 \mathrm{a}$ & $138.73 \mathrm{a}$ & $49.20 \mathrm{ab}$ & $49.9 \mathrm{a}$ & $117.43 \mathrm{a}$ & $118.8 \mathrm{a}$ \\
$60 \% \mathrm{~N}+0.2 \mathrm{CNTS}$ & $110.50 \mathrm{~d}$ & $128.16 \mathrm{c}$ & $39.97 \mathrm{de}$ & $41.62 \mathrm{de}$ & $111.43 \mathrm{ab}$ & $112.5 \mathrm{~d}$ \\
$60 \% \mathrm{~N}+0.4 \mathrm{CNTS}$ & $125.53 \mathrm{~b}$ & $126.86 \mathrm{c}$ & $48.80 \mathrm{ab}$ & $43.13 \mathrm{cde}$ & $105.40 \mathrm{~b}$ & $112.06 \mathrm{~d}$ \\
$60 \% \mathrm{~N}+0.6 \mathrm{CNTS}$ & $133.60 \mathrm{a}$ & $133.4 \mathrm{~b}$ & $39.50 \mathrm{e}$ & $45.19 \mathrm{bcd}$ & $110.26 \mathrm{ab}$ & $114.13 \mathrm{bcd}$ \\
$40 \% \mathrm{~N}+0.2 \mathrm{CNTS}$ & $115.13 \mathrm{c}$ & $127.4 \mathrm{c}$ & $45.17 \mathrm{bc}$ & $41.16 \mathrm{de}$ & $105.16 \mathrm{~b}$ & $113.8 \mathrm{bcd}$ \\
$40 \% \mathrm{~N}+0.4 \mathrm{CNTS}$ & $126.53 \mathrm{~b}$ & $126.86 \mathrm{c}$ & $43.73 \mathrm{~cd}$ & $42.4 \mathrm{de}$ & $111.03 \mathrm{ab}$ & $113.13 \mathrm{~d}$ \\
$40 \% \mathrm{~N}+0.6 \mathrm{CNTS}$ & $116.93 \mathrm{c}$ & $128.93 \mathrm{c}$ & $38.73 \mathrm{e}$ & $42.4 \mathrm{de}$ & $114.50 \mathrm{ab}$ & $116.5 \mathrm{abc}$ \\
\hline
\end{tabular}

Means having the same letter(s) within a column are insignificantly different at $5 \%$ level.

Table 6. Effect of nano carbon and nitrogen fertilization rates on yield, number and weight of cluster in Flame seedless grapes in 2014 and 2015 seasons

\begin{tabular}{|c|c|c|c|c|c|c|}
\hline \multirow[t]{2}{*}{ Treatment } & \multicolumn{2}{|c|}{ No. clusters/vine } & \multicolumn{2}{|c|}{ Cluster weight (g) } & \multicolumn{2}{|l|}{ Yield(kg) } \\
\hline & 2014 & 2015 & 2014 & 2015 & 2014 & 2015 \\
\hline $100 \% N$ (Cont.) & $32.33 \mathrm{ab}$ & $33.00 \mathrm{ab}$ & $440.67 \mathrm{a}$ & $443.33 a$ & $14.53 \mathrm{a}$ & $14.79 \mathrm{ab}$ \\
\hline $80 \% \mathrm{~N}+0.2 \mathrm{CNTS}$ & $25.33 a b c$ & $26.66 \mathrm{bcd}$ & $356.33 \mathrm{a}$ & $358.00 \mathrm{a}$ & $8.92 b$ & $9.47 \mathrm{bcd}$ \\
\hline $80 \% N+0.4 C N T S$ & $28.33 a b c$ & $29.66 \mathrm{abc}$ & $414.33 \mathrm{a}$ & $413.33 \mathrm{a}$ & $11.90 \mathrm{ab}$ & $12.37 \mathrm{abc}$ \\
\hline $80 \% N+0.6 C N T S$ & $33.33 \mathrm{a}$ & $34.33 a$ & $459.00 \mathrm{a}$ & $468.00 \mathrm{a}$ & $15.00 \mathrm{a}$ & $15.79 \mathrm{a}$ \\
\hline $60 \% \mathrm{~N}+0.2 \mathrm{CNTS}$ & $22.67 a b c$ & $28.33 \mathrm{abc}$ & $337.33 \mathrm{a}$ & $337.66 a$ & $9.73 \mathrm{ab}$ & $9.30 \mathrm{bcd}$ \\
\hline $60 \% N+0.4 C N T S$ & $25.00 \mathrm{c}$ & $23.33 \mathrm{~cd}$ & $341.33 \mathrm{a}$ & $345.00 a$ & $7.40 \mathrm{~b}$ & $7.82 \mathrm{~cd}$ \\
\hline $60 \% \mathrm{~N}+0.6 \mathrm{CNTS}$ & 29.67abc & $25.66 \mathrm{~cd}$ & $350.00 \mathrm{a}$ & $357.00 a$ & $8.67 \mathrm{~b}$ & $9.23 \mathrm{bcd}$ \\
\hline $40 \% N+0.2 C N T S$ & $21.33 \mathrm{c}$ & $21.00 \mathrm{~d}$ & $285.00 \mathrm{a}$ & $287.33 \mathrm{a}$ & $6.33 \mathrm{~b}$ & $6.22 d$ \\
\hline $40 \% N+0.4 C N T S$ & $23.33 b c$ & $23.33 \mathrm{~cd}$ & $326.67 \mathrm{a}$ & $331.00 \mathrm{a}$ & $7.65 \mathrm{~b}$ & $7.7 \mathrm{~cd}$ \\
\hline $40 \% \mathrm{~N}+0.6 \mathrm{CNTS}$ & $25.33 a b c$ & $25.33 \mathrm{~cd}$ & $329.00 \mathrm{a}$ & $328.66 \mathrm{a}$ & $8.17 \mathrm{~b}$ & $8.21 \mathrm{~cd}$ \\
\hline
\end{tabular}

Means having the same letter(s) within a column are insignificantly different at $5 \%$ level. 
Table 7. Effect of nano carbon and nitrogen fertilization rates on length and width of cluster, weight of 100 berries weight on Flame seedless grapes in 2014 and 2015 seasons

\begin{tabular}{|c|c|c|c|c|c|c|c|c|}
\hline \multirow[t]{2}{*}{ Treatment } & \multicolumn{2}{|c|}{$\begin{array}{c}\text { Cluster length } \\
(\mathrm{cm})\end{array}$} & \multicolumn{2}{|c|}{$\begin{array}{l}\text { Cluster width } \\
\text { (cm) }\end{array}$} & \multicolumn{2}{|c|}{$\begin{array}{c}\text { Weight of } 100 \\
\text { berries }(\mathrm{g})\end{array}$} & \multicolumn{2}{|c|}{$\begin{array}{c}\text { Juice weight/100 } \\
\text { berries }(\mathrm{g})\end{array}$} \\
\hline & 2014 & 2015 & 2014 & 2015 & 2014 & 2015 & 2014 & 2015 \\
\hline $100 \% N($ Cont.) & $22.83 a b$ & $24.00 \mathrm{a}$ & $15.3 a b$ & $15.66 a b c$ & $300.00 \mathrm{~cd}$ & $320.00 \mathrm{~b}$ & $136.00 \mathrm{~b}$ & $147.66 \mathrm{~b}$ \\
\hline $80 \% \mathrm{~N}+0.2 \mathrm{CNTS}$ & $21.67 b$ & $22.16 \mathrm{ab}$ & $14 \mathrm{bc}$ & 14.00 bcde & $295.00 \mathrm{de}$ & 291.33 cde & $123.00 \mathrm{c}$ & $135.33 \mathrm{~d}$ \\
\hline $80 \% \mathrm{~N}+0.4 \mathrm{CNTS}$ & $22.50 \mathrm{ab}$ & $23.50 \mathrm{ab}$ & $15.6 \mathrm{ab}$ & $16.00 \mathrm{ab}$ & $306.00 \mathrm{~b}$ & $314.66 \mathrm{~b}$ & $135.00 \mathrm{~b}$ & $141.33 \mathrm{c}$ \\
\hline $80 \% \mathrm{~N}+0.6 \mathrm{CNTS}$ & $24.33 \mathrm{a}$ & $24.33 \mathrm{a}$ & $16.6 \mathrm{a}$ & $16.66 \mathrm{a}$ & $312.00 \mathrm{a}$ & $336.66 \mathrm{a}$ & $181.00 \mathrm{a}$ & 178.00a \\
\hline $60 \% \mathrm{~N}+0.2 \mathrm{CNTS}$ & $22.00 \mathrm{~b}$ & $22.66 \mathrm{ab}$ & $13.3 \mathrm{bc}$ & 13.33de & $291.33 \mathrm{e}$ & 289.66 cde & $113.00 \mathrm{e}$ & 124.67 efg \\
\hline $60 \% \mathrm{~N}+0.4 \mathrm{CNTS}$ & $22.00 \mathrm{~b}$ & $22.33 \mathrm{ab}$ & $13.6 \mathrm{bc}$ & 14.00 bcde & $286.00 \mathrm{f}$ & 287.67 cde & $116.00 \mathrm{~d}$ & 127.67 ef \\
\hline $60 \% \mathrm{~N}+0.6 \mathrm{CNTS}$ & $22.00 \mathrm{~b}$ & $23.00 \mathrm{ab}$ & $15 a b$ & $15.16 \mathrm{abcd}$ & $304.00 b c$ & $296.66 \mathrm{c}$ & $117.00 \mathrm{~d}$ & $129.00 \mathrm{e}$ \\
\hline $40 \% \mathrm{~N}+0.2 \mathrm{CNTS}$ & $21.33 b$ & $21.66 b$ & $12.3 \mathrm{c}$ & $12.83 \mathrm{e}$ & $260.00 \mathrm{~h}$ & $275.00 \mathrm{e}$ & $109.00 \mathrm{f}$ & $114.33 \mathrm{~h}$ \\
\hline $40 \% \mathrm{~N}+0.4 \mathrm{CNTS}$ & 22.67ab & $22.66 \mathrm{ab}$ & $13.3 \mathrm{bc}$ & 13.50 cde & $266.00 \mathrm{~g}$ & 277.33 de & $109.00 \mathrm{f}$ & $120.00 \mathrm{gh}$ \\
\hline $40 \% \mathrm{~N}+0.6 \mathrm{CNTS}$ & 22.67ab & $22.66 \mathrm{ab}$ & $13.6 \mathrm{bc}$ & $13.00 \mathrm{de}$ & $281.00 \mathrm{f}$ & $292.33 \mathrm{~cd}$ & $119.00 \mathrm{~d}$ & $122.00 \mathrm{fg}$ \\
\hline
\end{tabular}

Means having the same letter(s) within a column are insignificantly different at $5 \%$ level.

Table 8. Effect of nano carbon and nitrogen fertilization rates on TSS, acidity and anthocyanin in Flame seedless grapes in 2014 and 2015 seasons

\begin{tabular}{|c|c|c|c|c|c|c|}
\hline \multirow{2}{*}{ Treatment } & \multicolumn{2}{|c|}{ TSS\% } & \multicolumn{2}{|c|}{ Acidity\% } & \multicolumn{2}{|c|}{ Anthocyanin $(\mathrm{mg} / 100 \mathrm{~g})$} \\
\hline & 2014 & 2015 & 2014 & 2015 & 2014 & 2015 \\
\hline $100 \% N($ Cont.) & $17.67 \mathrm{ab}$ & $17.33 a b$ & $0.83 \mathrm{a}$ & $0.83 \mathrm{a}$ & $34.72 b$ & $36.74 \mathrm{~b}$ \\
\hline $80 \% \mathrm{~N}+0.2 \mathrm{CNTS}$ & $16.63 \mathrm{bc}$ & $16.33 b c$ & $0.73 a b c$ & $0.66 \mathrm{~b}$ & $34.16 \mathrm{~b}$ & $26.90 \mathrm{~cd}$ \\
\hline $80 \% \mathrm{~N}+0.4 \mathrm{CNTS}$ & $17.33 \mathrm{abc}$ & $17.33 a b$ & $0.70 \mathrm{abc}$ & $0.70 a b$ & $32.66 \mathrm{bc}$ & $30.52 \mathrm{c}$ \\
\hline $80 \% \mathrm{~N}+0.6 \mathrm{CNTS}$ & $18.00 \mathrm{a}$ & $17.66 \mathrm{a}$ & $0.76 a b$ & $0.76 a b$ & $40.12 \mathrm{a}$ & $40.84 \mathrm{a}$ \\
\hline $60 \% \mathrm{~N}+0.2 \mathrm{CNTS}$ & $16.55 \mathrm{bc}$ & $16.00 \mathrm{c}$ & $0.73 a b c$ & $0.73 a b$ & $30.00 \mathrm{~cd}$ & $24.66 d$ \\
\hline $60 \% \mathrm{~N}+0.4 \mathrm{CNTS}$ & $17.00 \mathrm{abc}$ & $15.66 \mathrm{c}$ & $0.63 \mathrm{bc}$ & $0.73 a b$ & $28.16 \mathrm{de}$ & $24.48 d$ \\
\hline $60 \% \mathrm{~N}+0.6 \mathrm{CNTS}$ & $17.00 \mathrm{abc}$ & 17.33ab & $0.66 \mathrm{bc}$ & $0.63 b$ & $32.00 \mathrm{bc}$ & $27.02 \mathrm{~cd}$ \\
\hline $40 \% \mathrm{~N}+0.2 \mathrm{CNTS}$ & $16.54 \mathrm{bc}$ & $16.33 \mathrm{bc}$ & $0.60 \mathrm{c}$ & $0.70 \mathrm{ab}$ & $26.83 \mathrm{de}$ & $23.68 d$ \\
\hline $40 \% \mathrm{~N}+0.4 \mathrm{CNTS}$ & $16.33 \mathrm{c}$ & $16.33 \mathrm{bc}$ & $0.63 \mathrm{bc}$ & $0.63 \mathrm{~b}$ & $25.95 \mathrm{e}$ & $23.97 d$ \\
\hline $40 \% \mathrm{~N}+0.6 \mathrm{CNTS}$ & $16.67 \mathrm{bc}$ & $16.66 \mathrm{abc}$ & $0.76 \mathrm{ab}$ & $0.76 \mathrm{ab}$ & $29.95 \mathrm{e}$ & $26.11 d$ \\
\hline
\end{tabular}

Means having the same letter(s) within a column are insignificantly different at $5 \%$ level 
These results are in agreement with those reported by Husen and Siddiqi (2014) who reported that both functionalized and non-functionalized carbon nanomaterials influenced onfruit and crop production.

Finally, It could be concluded that the fertilization with $80 \% \mathrm{~N}$ from recommended requirment $+0.6 \% \mathrm{CNT}$ was the most effective treatment for increasing some vegetative parameters (leaf area, leaf fresh weight and leaf dry weight), some leaf mineral content ( $\mathrm{N}, \mathrm{P}, \mathrm{K}$ and $\mathrm{Mg}$ ), total carbohydrate, total chlorophyll, fruit quality (weight of 100 berries and juice weight of 100 berries and fruit skin anthocyanin content) of Flame seedless grapes.

\section{REFERENCES}

A.O.A.C., 1985. Association of official Analytical Chemist $14^{\text {th }}$ Ed. Benjamin Franklin Station, Washington, D.C., USA. pp. 490-510.

Begum, P., Ikhtiaria, R. and Fugetsu, B. 2014. Potential impact of multi-walled carbon nanotubes exposure to the seedling stage of selected plant species. Nanomaterials. 4, 203-221.

Brown, J. D. and Lilleland, D. 1946. Rapid determination of potassium and sodium in plant material and soil extract by flame photometry. Proc. Am. Soc. Hort. Sci. 48, 341-460.

Chinnamuthu C.R. and Boopathi P.M. 2009. Nanotechnology and Agroecosystem. Madras. Agric. J. 96, 17-31.

Cottenie, A., Verloo M., Kiekens L., Velgle G. and amerlynuck, R. 1982. Chemical Analysisof Plant and Soil.Laboratory of Analytical and Agroch. State Univ. of Belgium, Gent. pp. 43-51.

Duncan, D.B.C. 1955. Multiple Range and Multiple F. Tests. Biometrics. 11, 1-42.

Fan, I., Yunhe W., Xiwen S., Yanqiu G., Zhichun W., Yun M. and Jian, L. 2012. Effects of combined nitrogen fertilizer and nano-carbon application on yield and nitrogen use of rice grown on saline-alkali soil. J. of Food, Agric. \&Enviro. 10(1), 558-562.

Haghighi, M. and Teixeira da Silva, J.A. 2014. The Effect of Carbon Nanotubes on the Seed Germination andSeedling Growth of Four Vegetable Species. J. Crop Sci. Biotech. 17(4), 201- 208.

Husen, A. and Siddiqi, K.S. 2014. Carbon and fullerene nano materials in plant system, J. of Nano-biotechnology. 12, 16-26.
Husia, C.L., Luh, B.S. and Chichester, C.D. 1965. Anthocyanin in free stone. Peach. J. Food Science. 30, 5-12.

Jackson, M.L. 1967. Soil Chemical Analysis, New Jersey Prentice. Hall, Inc., Egleweed Cliffs, N.J. 331 p.

Khodakovskaya, M.V., de Silva K., Biris, A.S., Dervishi, E. and Villagarcia, H. 2012. Carbon nanotubes induce growth enhancement of tobacco cells. ACS Nano. 6, 2128-2135.

Lahiani,M.H., Enkeleda D., Ilia Ivanov, Jihua Chen and Khodakovskaya,M., 2016. Comparative study of plant responses to carbon based nanomaterials with different morphologies-based nonmaterial with different morphologies. Nanotechnology. 27, 26-34.

Liu, A.X. and Liao, Z.W. 2008. Effects of nanomaterials on water clusters.J. Anhui Agric. Sci. 36, 15780-15781.

Liu, Q., Chen, B., Wang, Q., Shi, X., Xiao, Z., Lin, J. and Fang, X. 2009. Carbon nanotubes as molecular transporters for walled plant cells. Nano Lett. 9, 1007-1010.

Ma, X., Geiser-Lee, J., Deng, Y. and Kolmakov, A. 2010. Interactions between engineered nanoparticles (ENPs) and plants: Phytotoxicityuptake and Accumulation. Science of the Total Environment. 408, 3053-3061.

M.A.L.R., 2015. Ministry of agriculture and land reclamation economic affairs, Egypt Agric. Directorates of Governorates. Vol. 2, 314.

Pregl, F. 1945. Quantitative organic microanalysis. $4^{\text {th }}$ Ed. J. and A. Churchill, Ltd., London.

Shaviv, A. 2000. Advances in controlled release of fertilizers. Adv. Agro. J. 71, 1-49.

Smith, F., Gilles, M.A, Hamilton, J.K. and Gedess, P.A. 1956. Colorimetric methods for determination of sugar and related substances. Anal. Chem., 28, 350-356.

Srivastava and Rao, D.P. 2014. Enhancement of seed germination and plant growth of wheat, maize, peanut and garlic using multi-walled carbon nanotubes. Eur. Chem. Bull. 3(5), 502504.

Taha R.A., Hassan M.M., Ibrahim, E.A., AboBakr, N.H. and Shaaban, E.A. 2016. Carbon nanotubes impact on date palm in vitro cultures.Pctoc.,127(2), 525-534.

Tisdale, S.L., Nelson, W.L. and Beaton, J.D. 1985.Soil fertility and fertilizers. Macmillan, New York, USA, pp. 20-30. 
Yield and Fruit Quality of Flame Seedless Grape

Truog, E. and Meyer, A.H. 1929. Improvements in the denigescolori-metric method for phosphorus and arsenic. Ind. Engng. Chern. Anal., Edl., pp. 136-139
Wood, C.W., Reeves, D.W. and Himelrick, D.G. 1992. Relationships between chlorophyll meter reading and leaf chlorophyll concentration. $\mathbf{N}$ status and crop yield. A review: Proc. Agro. Soc. N.Z. 23, 1-9. 